\title{
Pregnancy outcomes in inflammatory skin diseases
}

\section{Enflamatuvar deri hastalıklarında gebelik sonuçları}

\section{Duru Tabanlığlu Onan, ๑ Ahu Yorulmaz, ๑ Asiye Uğraș Dikmen*, ๑ Kadriye Yakut**, ๑ İsmail Güler***, ๑ Cemal Reșat Atalay**, ๑ Refika Ferda Artüz, ๑ Bașak Yalçın}

University of Health Sciences, Ankara Numune Training and Research Hospital, Clinic of Dermatology, Ankara, Turkey

*Gazi University Faculty of Medicine, Department of Public Health, Ankara, Turkey

**University of Health Sciences, Ankara Numune Training and Research Hospital, Clinic of Obstetrics and Gynecology, Ankara, Turkey

***Gazi University Faculty of Medicine, Department of Obstetrics and Gynecology, Ankara, Turkey

\begin{abstract}
Background and Design: Inflammation can lead to adverse outcomes in pregnancy. Some inflammatory diseases, such as rheumatoid arthritis, inflammatory bowel disease, systemic lupus erythematosus, and psoriasis, are associated with preterm birth and low birth weight. The objectives of our study were to assess the effect of various inflammatory skin diseases (ISDs) on pregnancy outcomes and to evaluate the course of ISDs during pregnancy.

Materials and Methods: In this multicenter cohort study, a total of 242 pregnant women in three groups including 32 pregnants with a history of ISDs, 70 pregnants with a diagnosis of systemic disease and 140 healthy pregnants were prospectively analyzed.

Results: The rate of adverse pregnancy outcome was $34.4 \%$ in ISDs, $37.1 \%$ in systemic diseases and $25 \%$ in healthy pregnant groups ( $p=0.16$ ). Gestational diabetes mellitus (12.5\%) and thyroid dysfunction in pregnancy $(9.4 \%)$ were the most common adverse outcomes of pregnancy seen in ISDs group. The disease course of ISDs was stable in $50 \%$, improved in $28.1 \%$ and exacerbated in $21.9 \%$ of patients during pregnancy. Conclusion: We could not demonstrate a significant association between ISDs and adverse pregnancy outcomes. Most of the ISDs were either stable or improved during pregnancy.
\end{abstract}

Keywords: Inflammation, skin diseases, pregnancy outcome, chronic disease

Öz

Amaç: Enflamasyon advers gebelik sonuçlarına yol açabilir. Romatoid artrit, enflamatuvar barsak hastalığı, sistemik lupus eritematozus ve psoriazis gibi enflamatuvar hastalıklar preterm doğum ve düşük doğum ağırlığı ile ilişkilendirilmektedir. Çalışmamızın amaçları çeşitli enflamatuvar deri hastalıklarının (EDH) gebelik sonuçlarına etkisini ve EDH'nin gebelikteki seyrini değerlendirmektir.

Gereç ve Yöntem: Bu çok merkezli kohort çalışmasında, EDH hikayesi olan 32 gebe, sistemik hastalık tanılı 70 gebe ve 140 sağlıklı gebe şeklinde üç gruba ayrılmış toplam 242 gebe prospektif olarak analiz edildi.

Bulgular: Advers gebelik sonucu oranı EDH grubunda \%34,4, sistemik hastalıklar grubunda \%37,1 ve sağlıklı gebe grubunda \%25 olarak tespit edildi $(p=0,16)$. Gestasyonel diabetes mellitus $(\% 12,5)$ ve gebelik dönemi tiroid disfonksiyonu $(\% 9,4)$ EDH grubunda en sık görülen advers gebelik sonuçlarıydı. EDH'nin gebelik boyunca seyri hastaların \%50'sinde stabil iken, \%28, 1'inde iyileşme, \%21,9'unda ise kötüleşme kaydedildi. Sonuç: EDH ve advers gebelik sonuçları arasında anlamlı bir ilişki gösterilemedi. EDH'nin çoğu gebelik döneminde ya stabil seyretti ya da düzeldi. Anahtar Kelimeler: Enflamasyon, deri hastalıkları, gebelik sonucu, kronik hastalık

\section{Introduction}

Inflammation can lead to adverse pregnancy outcomes, such as preterm birth (PTB) and low birth weight (LBW) ${ }^{1}$. With this regard, it was evidenced that some inflammatory diseases, such as rheumatoid arthritis (RA), inflammatory bowel disease, systemic lupus erythematosus (SLE), and psoriasis, are related with PTB, LBW and abortions ${ }^{2-6}$. Perinatal mortality

Address for Correspondence/Yazışma Adresi: Duru Tabanlıoğlu Onan MD, University of Health Sciences, Ankara Numune Training and Research Hospital, Clinic of Dermatology, Ankara, Turkey Phone: +90 5326284896 E-mail: t_duru@hotmail.com

Received/Geliş Tarihi: 11.01.2018 Accepted/Kabul Tarihi: 18.06.2018 ORCID ID: orcid.org/0000-0003-2582-1561

CCopyright 2018 by Turkish Society of Dermatology and Venereology

Turkderm-Turkish Archives of Dermatology and Venereology published by Galenos Yayınevi. 
and morbidity are increased significantly in SLE; and the incidence of spontaneous abortions is increased in $\mathrm{RA}^{7}$. The rates of intrauterine growth restriction (IUGR) and caesarean delivery have been reported to be slightly higher in patients with multiple sclerosis than in the general obstetric population?

Psoriasis is an ideal model to understand the pathogenesis of the development of the pregnancy complications due to inflammation. Proinflammatory cytokines of active psoriasis, such as interleukin-6 (IL), C-reactive protein (CRP), and tumor necrosis factor- $\alpha$ (TNF- $\alpha$ ), are known to be increased in pregnancies complicated with PTB or small for gestational age neonates ${ }^{1,9-11}$. Autoimmune inflammation in psoriasis with excess cytokine production results in endothelial dysfunction which then gives rise to systemic and placental vasculopathy ${ }^{4,12}$ Placental vasculopathy has been assumed to cause LBW infants ${ }^{4}$. LBW is also a complication of pre-eclampsia that is related with an activated inflammatory state and increased levels of the same cytokines (CRP, TNF- $\alpha$ and IL-6) similar to that in psoriasis ${ }^{12-14}$.

Almost all the studies about the effects of inflammatory skin diseases (ISDs) on pregnancy outcomes have been carried out with psoriasis patients ${ }^{1,7,15,16}$. Yet, there is a gap in the literature regarding impact of ISDs other than psoriasis on pregnancy.

The primary aim of our study was to evaluate the possible effects of ISD on pregnancy outcomes by comparing the outcomes of pregnants with ISD both with pregnants who have systemic disease and healthy status. Our secondary objective was to assess the course of ISD during pregnancy.

\section{Materials and Methods}

This study was designed as a multicenter, cohort study. A total of 242 pregnant women from two different centers - a university hospital and a research hospital - divided into 3 groups were included in the analysis. Institutional Ethics Committee of the Gazi University approved the project (approval number: 77082166-604.01.02/111) and verbal informed consent was obtained from the subjects. All the pregnant women recruited to the study were questioned for the history of systemic diseases, medical therapies, the course and treatment of ISD during pregnancy, and previous pregnancy complications. The pregnants were followed up and the pregnancy outcomes were recorded after delivery.

The first group included 32 pregnant women with a history of at least one ISD that was diagnosed before pregnancy and persisted during pregnancy. The second group included 70 pregnant women with the diagnosis of a systemic disease that is known to have an impact on the pregnancy outcomes. The third group included 140 pregnants with healthy status. Women with any systemic disease were not included in the ISD group. Women with pregnancy dermatoses in their current pregnancy were excluded from the study.

\section{Statistical Analysis}

Descriptive statistics were presented by frequencies, percentages and median (minimum, maximum) values. Categorical data were compared by Pearson's chi-square test. All comparisons were made for a two tailed significance level of 0.05 . Statistical analyses were performed with SPSS 21.0 for Windows. The power of the study was calculated as $86 \%(0.86)$; with a sample size of 242 and alpha value of $5 \%(0.05)$.

\section{Results}

ISD group was composed of 32 pregnant women with a history of at least one ISD (psoriasis, atopic dermatitis, vitiligo, lichen planus, seborrheic dermatitis, contact dermatitis, nummular dermatitis, lichen simplex chronicus, rosacea, chronic urticaria, and alopecia areata) (Table 1). Systemic disease group was composed of 70 pregnant women with the diagnosis of a systemic disease (thyroid disease, coagulopathy, coronary artery disease, diabetes mellitus (DM), hypertension, rheumatologic disease, hematologic disease, epilepsy, asthma, migraine) (Table 2). The median age of the ISD group was 28 (17-46) years, the systemic disease group was $32(20-43)$ years and the healthy group was 29 (20-41) years. There was no significant difference in terms of age between the 3 groups (ANOVA test; $p=0.191$ ).

The percentages of cigarette smoking during pregnancy were $12.5 \%$ in the ISD, 8.6\% in the systemic disease and 5\% in the healthy groups. There was no significant difference between the groups $(p=0.272)$. The rates of alcohol intake during pregnancy were $3.1 \%(n=1)$ in the ISD

Table 1. The distribution of the inflammatory skin disease types in the inflammatory skin disease group

\begin{tabular}{|l|l|l|}
\hline Types of inflammatory skin diseases & $\mathbf{n}$ & $\%$ \\
\hline Psoriasis & 9 & 28.1 \\
\hline Seborrheic dermatitis & 8 & 25.0 \\
\hline Contact dermatitis & 4 & 12.5 \\
\hline Nummular dermatitis & 3 & 9.4 \\
\hline Lichen simplex chronicus & 2 & 6.3 \\
\hline Vitiligo & 1 & 3.1 \\
\hline Lichen planus & 1 & 3.1 \\
\hline Atopic dermatitis & 1 & 3.1 \\
\hline Rosacea & 1 & 3.1 \\
\hline Alopecia areata & 1 & 3.1 \\
\hline Chronic urticaria & 1 & 3.1 \\
\hline Total & 32 & 100.0 \\
\hline n: Number of the patients & & \\
\hline
\end{tabular}

Table 2. The distribution of the systemic disease types in the systemic disease group

\begin{tabular}{|l|l|l|}
\hline Types of systemic diseases & $\mathbf{n}$ & \% \\
\hline Thyroid disease & 17 & 24.3 \\
\hline Coagulopathy & 16 & 22.9 \\
\hline Coronary artery disease & 8 & 11.4 \\
\hline Diabetes mellitus & 7 & 10.0 \\
\hline Hypertension & 6 & 8.6 \\
\hline Rheumatologic disease & 4 & 5.7 \\
\hline Hematologic disease & 4 & 5.7 \\
\hline Epilepsy & 4 & 5.7 \\
\hline Asthma & 3 & 4.3 \\
\hline Migraine & 1 & 1.4 \\
\hline Total & 70 & 100.0 \\
\hline n: Number of the patients & & \\
\hline
\end{tabular}


and $0.7 \%(n=1)$ in the healthy groups. None of the pregnants with systemic diseases consumed alcohol during pregnancy. There was no significant difference between the groups $(p=0.263)$. The groups were also similar in terms of gravidity, parity and number of children alive. There was no difference in the mean duration of pregnancy between the ISD group (38.88 \pm 1.29$)$ and the other groups $(p=0.384)$, but there was a significant difference in the mean duration of pregnancy between the systemic disease group $(37.86 \pm 2.96)$ and the healthy group (38.60 \pm 1.67$)(p=0.021)$.

The delivery method was caesarean section in $43.8 \%$ of the ISD group, $67.1 \%$ of the systemic disease group and $54.3 \%$ of the healthy group $(p=0.020)$. One of the pregnant women with a systemic disease had spontaneous abortus. The caesarean rate in the systemic disease group was significantly higher than in the other groups $(p<0.05)$, but there was no difference in caesarean rates between the ISD and the healthy groups ( $p=0.329)$.

Adverse pregnancy outcomes (obstetric risk factors and labor complications) were present in $34.4 \%$ of pregnants with ISD, $37.1 \%$ of pregnants with systemic diseases and $25 \%$ of the healthy pregnants $(p=0.160)$. There was no significant difference between the ISD group

Table 3. Adverse pregnancy outcomes in terms of obstetric risk factors by study group

\begin{tabular}{|c|c|c|c|c|}
\hline Obstetric risk factors & Group 1 & Group 2 & Group 3 & p-value \\
\hline Pre-eclampsia & $1(3.1 \%)$ & $5(7.1 \%)$ & $1(0.7 \%)$ & 0.03 \\
\hline Abortus imminens & 0 & $1(1.4 \%)$ & 0 & 0.29 \\
\hline $\begin{array}{l}\text { Gestational diabetes } \\
\text { mellitus }\end{array}$ & $4(12.5 \%)$ & $7(10 \%)$ & $11(7.9 \%)$ & 0.68 \\
\hline $\begin{array}{l}\text { Gestational } \\
\text { hypertension }\end{array}$ & $1(3.1 \%)$ & $1(1.4 \%)$ & $3(2.1 \%)$ & 0.85 \\
\hline $\begin{array}{l}\text { Thyroid dysfunction in } \\
\text { pregnancy }\end{array}$ & $3(9.4 \%)$ & $4(5.7 \%)$ & $3(2.1 \%)$ & 0.13 \\
\hline $\begin{array}{l}\text { Gestational } \\
\text { thrombocytopenia }\end{array}$ & 0 & 0 & $1(0.7 \%)$ & 0.69 \\
\hline $\begin{array}{l}\text { Gestational } \\
\text { cholestasis }\end{array}$ & 0 & 0 & $1(0.7 \%)$ & 0.69 \\
\hline Placenta previa & 0 & $2(2.9 \%)$ & $6(4.3 \%)$ & 0.46 \\
\hline Placenta percreta & 0 & $1(1.4 \%)$ & $1(0.7 \%)$ & 0.74 \\
\hline Oligohydramnios & $1(3.1 \%)$ & $1(1.4 \%)$ & $2(1.4 \%)$ & 0.78 \\
\hline Polyhydramnios & $1(3.1 \%)$ & 0 & $2(1.4 \%)$ & 0.39 \\
\hline $\begin{array}{l}\text { Premature rupture of } \\
\text { membranes }\end{array}$ & 0 & $1(1.4 \%)$ & $1(0.7 \%)$ & 0.74 \\
\hline Fetal distress & 0 & $4(5.7 \%)$ & $6(4.3 \%)$ & 0.40 \\
\hline $\begin{array}{l}\text { Preterm delivery } \\
\text { threat }\end{array}$ & $1(3.1 \%)$ & $1(1.4 \%)$ & $1(0.7 \%)$ & 0.53 \\
\hline IUGR & $1(3.1 \%)$ & $1(1.4 \%)$ & 0 & 0.17 \\
\hline Macrosomia & 0 & $1(1.4 \%)$ & $3(2.1 \%)$ & 0.68 \\
\hline $\begin{array}{l}\text { Thrombotic } \\
\text { complications }\end{array}$ & 0 & $1(1.4 \%)$ & 0 & 0.29 \\
\hline
\end{tabular}

IUGR: Intrauterine growth restriction, Group 1: Inflammatory skin disease group;

Group 2: Systemic disease group; Group 3: Healthy group and the other groups ( $p>0.05)$. When we compared the systemic disease and the healthy groups, the adverse pregnancy outcomes were encountered more frequently in the systemic disease group, that was close to the level of statistical significance $(p=0.077)$. The types of adverse pregnancy outcomes seen in pregnants with ISD were gestational diabetes mellitus (GDM) (12.5\%), thyroid disease during pregnancy $(9.4 \%)$, gestational hypertension $(3.1 \%)$, pre-eclampsia (3.1\%), IUGR (3.1\%), oligohydramnios (3.1\%), polyhydramnios (3.1\%), preterm delivery threat (3.1\%), and PTB (3.1\%) (Table 3,4).

Of the 32 ISD patients, 14 was suffering from ISD during their previous pregnancies; and $35.7 \%(n=5)$ of those 14 patients reported a past adverse pregnancy outcome (abortus, GDM, polyhydramnios, intrauterine exitus) which was similar to the rate of present adverse pregnancy outcomes (34.4\%).

Thyroid dysfunction appearing during pregnancy, in the form of hyperthyroidism or hypothyroidism, was detected in $9.4 \%(n=3)$ of the ISD, $2.8 \%(n=2)$ of the systemic disease and $2.1 \%(n=3)$ of the healthy group $(p=0.121)$. The difference in the frequency of thyroid dysfunction in pregnancy between the ISD and systemic disease groups was not significant $(p=0.160)$, however when the ISD group was compared with the healthy group, thyroid dysfunction was detected much more frequently in the ISD group, close to the level of statistical significance $(p=0.079)$.

Pre-eclampsia developed in $3.1 \%$ of the ISD group, $7.1 \%$ of the systemic disease group and $0.7 \%$ of the healthy group $(p=0.032)$. There was no significant difference between the ISD group and the other groups, but the difference between the systemic disease and the healthy groups was significant $(p=0.016)$.

The births were preterm in $3.1 \%$ of the ISD group, $15.7 \%$ of the systemic disease group and $6.4 \%$ of the healthy group. The difference between the 3 groups was significant $(p=0.039)$. The difference between the systemic disease and the healthy groups was significant $(p=0.006)$. However, there was no significant difference between the ISD and the healthy pregnants groups $(p=0.343)$ and pregnants with systemic disease $(p=0.432)$ in terms of PTB. One of the pregnants with rheumatic disease $(n=4)$ in the systemic disease group, whose

Table 4. Adverse pregnancy outcomes in terms of labor complications by study group

\begin{tabular}{|l|l|l|l|l|}
\hline Labor complications & Group 1 & Group 2 & Group 3 & p-value \\
\hline $\begin{array}{l}\text { Preterm birth } \\
(<37 \text { weeks })\end{array}$ & $1(3.1 \%)$ & $11(15.7 \%)$ & $9(6.4 \%)$ & 0.04 \\
\hline $\begin{array}{l}\text { Low birth weight } \\
(<2500 \text { gr })\end{array}$ & 0 & $4(5.7 \%)$ & $3(2.1 \%)$ & 0.20 \\
\hline Non-progressive labor & 0 & 0 & $2(1.4 \%)$ & 0.48 \\
\hline Breech arrival & 0 & 0 & $3(2.1 \%)$ & 0.33 \\
\hline $\begin{array}{l}\text { Meconium } \\
\text { aspiration }\end{array}$ & 0 & $1(1.4 \%)$ & $1(0.7 \%)$ & 0.74 \\
\hline Pneumothorax & 0 & 0 & $1(0.7 \%)$ & 0.69 \\
\hline Still birth & 0 & $1(1.4 \%)$ & $1(0.7 \%)$ & 0.74 \\
\hline $\begin{array}{l}\text { Postnatal exitus } \\
\text { Proup 1: Inflammatory skin disease group; Group 2: Systemic disease group; Group }\end{array}$ \\
\hline \begin{tabular}{l} 
3: Healthy group \\
\hline
\end{tabular} & 0 & $1(1.4 \%)$ & 0 & 0.29 \\
\hline
\end{tabular}


pregnancy resulted with PTB and LBW, had SLE. None of the births were postterm.

Twenty-two (68.7\%) pregnants with ISD used topical treatment before pregnancy; 5 (15.6\%) patients used systemic treatment and $8(25 \%)$ patients did not receive any treatment. There was no significant difference in adverse pregnancy results when the patients were evaluated according to their treatment history before pregnancy $(p=0.153)$. When the disease course during pregnancy was evaluated, the disease was stable in 50\% ( $n=16)$, improved in $28.1 \%(n=9)$ and exacerbated in $21.9 \%(n=7)$ of patients with ISD.

\section{Discussion}

In this prospective cohort study, we evaluated the effect of ISD on pregnancy outcomes by comparing the outcomes in pregnant women with ISD with both pregnants who have systemic disease and healthy pregnants. However, we could not detect a significant difference in the outcomes of pregnancy between the pregnant women with and without ISD. The rate of complications in previous pregnancies in pregnants with ISD, which would reflect the adverse pregnancy outcomes retrospectively, was not different from the rate of present adverse pregnancy outcomes. The risk of developing pre-eclampsia in pregnants with ISD was not different from that in pregnant women with systemic diseases and the healthy pregnant women. There was no significant difference between the pregnant women with ISD and the other two groups in terms of PTB.

Almost all of the studies about the effects of ISD on pregnancy outcomes have been carried out with psoriasis patients $1,7,15,16$. This may be attributed to more prominent adverse outcomes that have been encountered in psoriasis due to higher intensity of inflammation than in many other ISDs. Furthermore, comorbidities of psoriasis might have been increasing the probability of complications. Cohen-Barak et al. ${ }^{5}$ found that the risk for spontaneous and induced abortions is increased in psoriasis, similar to that in other inflammatory conditions such as RA and SLE. Ben-David et al. ${ }^{7}$, in a case-control study, demonstrated that patients with psoriasis were at an increased risk for pregnancy complications, such as recurrent abortions, chronic hypertension and caesarean deliveries. Bandoli et al. ${ }^{15}$ suggested that the risk of pregnancy complications such as hypertension might be increased in pregnant psoriatic women. Lima et al. ${ }^{1}$, in a retrospective study, found that psoriasis was associated with a poor outcome composite, including PTB and LBW. Nevertheless, in their study, psoriasis was not related to caesarean delivery, pre-eclampsia/eclampsia, or spontaneous abortion. Horev et al. ${ }^{17}$ conducted a retrospective comparative study to estimate the relationship between vitiligo and adverse pregnancy outcomes. According to the results of this study, there was no association between vitiligo and adverse pregnancy outcomes including obstetric risk factors, labor characteristics and complications, and birth outcome. Seeger et al. ${ }^{18}$, for the first time, investigated the effect of ISD, including not only psoriasis but also atopic dermatitis, vitiligo, lichen planus, seborrheic dermatitis and contact dermatitis, on pregnancy outcomes in a retrospective cohort study. The aim of their study was to find out and compare the incidence and outcomes of pregnancy in women with ISD and women without ISD. The incidence of pregnancy was similar in both groups. The incidence of spontaneous abortion in the groups was also close to each other. Likewise, in our study the rates of both spontaneous abortion and abortions in general were not different between ISD and healthy groups. Similar to our study, they could not detect a significant difference in the outcomes of pregnancy between pregnant women with and without ISD.

Thyroid dysfunction in pregnancy was the only outcome that was detected more common in pregnants with ISD than in both the pregnants who have systemic disease and the healthy pregnants. However, only the difference in the frequency of thyroid dysfunction in pregnancy between pregnants with ISD and the healthy pregnant women was close to the level of statistical significance.

Thyroid dysfunction in pregnancy can appear as hyperthyroidism, hypothyroidism, subclinical thyroid dysfunction and thyroid autoimmune antibody positivity. Overt hyperthyroidism has been associated with miscarriage, stillbirth, PTB, IUGR, LBW, pre-eclampsia and fetal thyroid dysfunction. Overt hypothyroidism has been associated with abortion, anemia, pregnancy-induced hypertension, pre-eclampsia, placental abruption, postpartum hemorrhage, PTB, LBW, intrauterine fetal death, increased neonatal respiratory distress, and infant neuro developmental dysfunction. However, the adverse effects of subclinical thyroid dysfunction and thyroid autoimmunity on pregnancy outcomes are not clear ${ }^{19}$.

Although no other adverse pregnancy outcome was accompanying thyroid dysfunction in pregnancy for those pregnants with ISD in our study, presence of thyroid dysfunction in pregnancy may be accepted as a risk factor for the development of other pregnancy complications. The secondary objective of our study was to evaluate the disease course of ISD during pregnancy. Pregnancy influences immunologic pathways. Maternal immune response is suppressed during pregnancy, as a result of the interaction between the pregnancy-related hormones and the immune system ${ }^{20}$. The shift of the immune response from Th1 to Th2 dominance leads to the improvement in Th1 - mediated autoimmune diseases such as psoriasis, RA and multiple sclerosis ${ }^{21}$. ISD was stable in $50 \%$, improved in $28.1 \%$ and exacerbated in $21.9 \%$ of the patients in our study.

\section{Study Limitations}

The small number of pregnant women in the ISD group with respect to systemic disease group and the healthy group was the main limitation of our study. Studies with higher number of pregnants with ISD might reflect the actual effect of the ISD on the pregnancy outcomes.

\section{Conclusion}

In this study, we evaluated the effect of ISD on pregnancy outcomes, however, we could not detect a significant difference in the outcomes of pregnancy between pregnant women with and without ISD. This result may be attributed to the limited number of pregnant women with ISD included in the study compared to the number of healthy pregnant women and pregnant women with systemic diseases. Moreover, since the intensity of inflammation in ISD other than psoriasis would be expected to be lower, the incidence of adverse outcomes might be decreasing in a heterogeneous group of ISD patients with regard to studies carried out only with psoriasis patients.

Thyroid dysfunction in pregnancy was the only outcome that was encountered more common in pregnant women with ISD than in healthy pregnant women in our study. Based on from here, we suggest 
that higher rates of thyroid dysfunction accompanying pregnancy with ISD may be accepted as a risk factor that can affect pregnancy outcomes indirectly. We also evaluated the disease course of ISD during pregnancy and detected that most of the ISDs were either stable or improved during pregnancy.

\section{Ethics}

Ethics Committee Approval: Gazi University Institutional Ethics Committee (approval number: 77082166-604.01.02/111).

Informed Consent: Verbal informed consent was obtained from all the patients included in the study.

Peer-review: Externally peer-reviewed.

\section{Autorship Contributions}

Surgical and Medical Practices: D.T.O., A.Y., K.Y., Consept: D.T.O., I.G., C.R.A., R.F.A., B.Y., Design: D.T.O., A.U.D., I.G., C.R.A., R.F.A., B.Y., Data Collection or Processing: D.T.O., A.Y., K.Y., Analysis or Interpretation: D.T.O., A.U.D., Literature Search: D.T.O., Writing: D.T.O.

Conflict of Interest: No conflict of interest was declared by the authors.

Financial Disclosure: The authors declared that this study received no financial support.

\section{References}

1. Lima $X T$, Janakiraman $V$, Hughes MD, Kimball $A B$ : The impact of psoriasis on pregnancy outcomes. J Invest Dermatol 2012;132:85-91.

2. Cornish J, Tan E, Teare J, et al: A meta-analysis on the influence of inflammatory bowel disease on pregnancy. Gut 2007;56:830-7.

3. Lin $\mathrm{HC}$, Chen SF, Lin $\mathrm{HC}$, Chen $\mathrm{YH}$ : Increased risk of adverse pregnancy outcomes in women with rheumatoid arthritis: a nationwide population based study. Ann Rheum Dis 2010;69:715-7.

4. Yang YW, Chen CS, Chen YH, Lin HC: Psoriasis and pregnancy outcomes: a nationwide population-based study. J Am Acad Dermatol 2011;64:71-7.

5. Cohen-Barak E, Nachum Z, Rozenman D, Ziv M: Pregnancy outcomes in women with moderate-to-severe psoriasis. J Eur Acad Dermatol Venereol 2011;25:1041-7.

6. Landau JM, Moody MN, Kazakevich N, Goldberg LH: Psoriasis and the pregnant woman: what are the key considerations? Skin Therapy Lett 2011;16:1-3.
7. Ben-David G, Sheiner E, Hallak M, Levy A: Pregnancy outcome in women with psoriasis. J Reprod Med 2008;53:183-7.

8. Kelly VM, Nelson LM, Chakravarty EF: Obstetric outcomes in women with multiple sclerosis and epilepsy. Neurology 2009;73:1831-6.

9. Sorokin $Y$, Romero $R$, Mele $L$, et al: Maternal serum interleukin- $6, C$ reactive protein, and matrix metalloproteinase- 9 concentrations as risk factors for preterm birth $<32$ weeks and adverse neonatal outcomes. Am J Perinatol 2010;27:631-40

10. Amarilyo G, Oren A, Mimouni FB, Ochshorn $Y$, Deutsch V, Mandel D: Increased cord serum inflammatory markers in small-for-gestational-age neonates. J Perinatol 2011;31:30-2.

11. Bastek JA, Brown AG, Anton L, Srinivas SK, D'addio A, Elovitz MA: Biomarkers of inflammation and placental dysfunction are associated with subsequent preterm birth. J Matern Fetal Neonatal Med 2011;24:600-5.

12. Guven MA, Coskun A, Ertas IE, Aral M, Zencirci B, Oksuz H: Association of maternal serum CRP, IL-6, TNF-alpha, homocysteine, folic acid and vitamin B12 levels with the severity of preeclampsia and fetal birth weight. Hypertens Pregnancy 2009;28:190-200.

13. Redman CW, Sacks GP, Sargent IL: Preeclampsia: an excessive maternal inflammatory response to pregnancy. Am J Obstet Gynecol 1999;180:499506.

14. Sacks GP, Studena K, Sargent K, Redman CW: Normal pregnancy and preeclampsia both produce inflammatory changes in peripheral blood leukocytes akin to those of sepsis. Am J Obstet Gynecol 1998;179:80-6.

15. Bandoli $\mathrm{G}$, Johnson $\mathrm{DL}$, Jones $\mathrm{KL}$, et al: Potentially modifiable risk factors for adverse pregnancy outcomes in women with psoriasis. Br J Dermatol 2010;163:334-9

16. Horn EJ, Chambers $C D$, Menter $A$, Kimball $A B$; International Psoriasis Council: Pregnancy outcomes in psoriasis: why do we know so little? J Am Acad Dermatol 2009;61:5-8.

17. Horev A, Weintraub AY, Sergienko R, Wiznitzer A, Halevy S, Sheiner E: Pregnancy outcome in women with vitiligo. Int J Dermatol 2011;50:1083-5.

18. Seeger JD, Lanza LL, West WA, Fernandez C, Rivero E: Pregnancy and pregnancy outcome among women with inflammatory skin diseases. Dermatology 2007;214:32-9.

19. Nazarpour S, Ramezani Tehrani F, Simbar M, Azizi F: Thyroid dysfunction and pregnancy outcomes. Iran J Reprod Med 2015;13:387-96.

20. Raychaudhuri SP, Navare T, Gross J, Raychaudhuri SK: Clinical course of psoriasis during pregnancy. Int J Dermatol 2003;42:518-20.

21. Murase JE, Chan KK, Garite TJ, Cooper DM, Weinstein GD: Hormonal effect on psoriasis in pregnancy and post partum. Arch Dermatol 2005;141:601-6. 